\title{
Efficiency of private pension funds in Poland
}

\author{
Kompa, Krzysztof \\ Witkowska, Dorota \\ - RECEIVED: 3 MaRCH 2015 \\ - accepted: 8 JUNe 2015
}

\begin{abstract}
The changing demographics in most European countries requires reform of their retirement systems in order to adapt them to the current situation. EU states' pension fund systems therefore have to undergo essential transformations. The primary reform of the pension system in Poland took place in 1999, when the one-pillar, pay-as-yougo system, was replaced by the three-pillar system: mandatory, pay-as-you-go pillar; mandatory, fully-funded pillar; and voluntary, funded pillar. However, the pension system in Poland was subject to government manipulation. The most important changes, concerning pension fund contributions and portfolio composition, came into effect in 2011 and 2014. The aim of this research is to analyze the efficiency of the pension funds operating in Poland in the period 1999-2013, by applying the Sharpe and Treynor ratios and comparing the pension fund performance to that of the benchmarks constructed to illustrate the changes to pension fund portfolio composition.
\end{abstract}

\section{Keywords:}

Pension system, Pension funds, Efficiency, Sharpe ratio, Treynor ratio.

\section{JEL classification:}

G11, H55, J26, J32.

Kompa, K. The Warsaw University of Life Sciences, Dep. of Econometrics and Statistics, Chair of Financial Engineering, 166 Nowoursynowska St., 02-787 Warsaw, Poland. E-mail: krzysztof_kompa@sggw.pl 


\title{
La eficiencia de los fondos de pensiones privados en Polonia
}

\author{
Kompa, Krzysztof \\ Witkowska, Dorota
}

\section{Resumen}

A la luz de los cambios demográficos habidos en la mayoría de los países europeos, los sistemas de jubilación han tenido que reformarse para adaptarse a la situación actual. En consecuencia, los países de la Unión Europea han realizado cambios trascendentales en sus sistemas de fondos de pensiones. La principal reforma del sistema de pensiones polaco se llevó a cabo en 1999, cuando sistema de reparto (único pilar) fue sustituido por el sistema de tres pilares: el sistema de reparto, obligatorio; un pilar obligatorio plenamente capitalizado; $y$ un pilar financiado con contribuciones voluntarias. No obstante, el sistema de pensiones polaco se ha convertido en objeto de manipulaciones gubernamentales. Las modificaciones más relevantes, en lo que se refiere a contribuciones a los fondos de pensiones y composición de carteras de fondos de pensiones, entraron en vigor en 2011 y 2014. El objetivo de este artículo es analizar la eficiencia de los fondos de pensiones que operaban en Polonia en el periodo 19992013 mediante los ratios de Sharpe y Treynor, así como comparar el rendimiento de los fondos de pensiones con los benchmarks construidos al efecto, lo cual ilustra los cambios en la composición de los fondos de pensiones.

\section{Palabras clave:}

Sistema de pensiones, fondos de pensiones, ratio de Sharpe, ratio de Treynor. 


\section{Introduction}

The significant increase in old-age-dependency ratios ${ }^{1}$ in most European countries requires retirement system reform. The primary pension system reform consists of raising the age of retirement and introducing funded systems instead of pay-as-yougo (PAYG) systems. The most frequent reason given in the public policy debate for a funded system is the apparently superior performance of the capital market in terms of the rates of return it can offer on pension investments. However, the risk of such investments must also be taken into account. Indeed, many studies have shown how poor the rates of return on investment really are for PAYG pension contributions (Feldstein, 1997; Sinn, 2000). It is now widely accepted in most developed countries that pension systems and rules need to be modified over time, although such changes may vary from country to country ${ }^{2}$.

The main reform of the pension system in Poland was introduced in 1999. The new system consisted of three pillars: a pay-as-you-go pillar and a fully-funded pillar - both of which were mandatory - , along with a voluntary, funded pillar. In recent years, the Polish government has introduced several changes, including amendments to:

the retirement age, which increased to 67 years old for both sexes (from 65 for men and 60 for women), with partial benefits available to those who retire earlier (since January 2013 the retirement age has been increasing by 3 months each year), the contribution of earnings saved in both of the mandatory pillars (in 2011),

the role of the mandatory funded pillar that became voluntary from July 2013, the allocation of investments i.e. pension fund portfolio composition, especially the ban on investing in debt securities issued and guaranteed by the State Treasury (in 2014).

The aim of our research is to analyze the efficiency of the private pension funds operating in Poland in the period 1999-2013, compare their performance to that of constructed benchmarks, and assess the effects of the changes to pension fund portfolio composition introduced by the government in 2014. In the analysis, the Sharpe and Treynor ratios are calculated on the basis of monthly returns from the accounting units in the period from 17 August 1999 to 17 October 2013. The analysis is performed separately for different sub-periods when certain market trends are observed (i.e. bull, bear and neutral market).

\footnotetext{
${ }^{1}$ Old-age-dependency ratio is the population aged 65 and over divided by the population aged 15-64 (Eurostat).

${ }^{2}$ The key objectives of the pension reform are discussed in Pension at a Glance (2013, p. I8), along with policies to diversify and secure retirement savings $(20 / 3$, p. 25).
} 
After this brief introductory section, Section 2 describes the pension system in Poland, Section 3 focuses on the open pension funds operating in the country, Section 4 describes the data and methods used in this research, Section 5 contains the empirical analysis of the efficiency of the private pension funds, and Section 6 concludes.

\section{The pension system in Poland}

The 1999 Polish pension system reform introduced two important changes ${ }^{3}$. The first entailed the addition of a funded scheme to the mandatory system, while the second consisted of replacing a defined benefit system with a defined contribution system. Before 1999, the pension benefit was an ex ante known proportion of the wages that had been received prior to retirement. Since 1999, pensions have consisted of an individual's stock of savings divided by one's remaining lifetime. In order to implement the defined contribution scheme, the legislation specified a so-called "initial capital", calculated for all individuals based on their employment tenure using algorithms differentiated across genders and education levels ${ }^{4}$.

The 1999 reforms introduced a three-pillar pension benefits system. The first and second pillars were universal and mandatory while the third was voluntary. The first pillar remained a PAYG financed system, whereas the second and third pillars were funded systems. In fact, the PAYG system which formed the first pillar was downsized and became a "notional defined-contribution" system. In both the first and the second funded pillars, contributions were registered in individual accounts and the pension benefits depended on contributions paid, not contributions that were due ${ }^{5}$.

The first pillar is governed by the Social Insurance Institution (ZUS in Polish) while the mandatory second pillar is managed by Open Pension Funds (OFE in Polish); all workers were to contribute to these two pillars. A contribution of $12.22 \%$ of earnings ${ }^{6}$ was credited to individuals' notional accounts, while $7.3 \%$ of earnings was to be transferred to the pension funds which made up the second mandatory pillar, for a total contribution of $19.52 \%$.

\footnotetext{
${ }^{3}$ The authors of this program for pension system reform called it "Security through Diversity" (Security, 1997).

${ }^{4}$ Of course there were no savings in the ZUS but this method of calculation allowed the valuation of pensions for those born too early to participate in the new pension system. Individuals who collected pensions in 1999 and were less than 10 years from their official retirement age, were exempt from the new system (Hagemejer et al., 2013). The new scheme was introduced as a system of notional accounts. People under 30 (born in 1969 and after) at the time of the reform also had to participate in the funded scheme; people aged 30-50 (born between 1949 and 1968) could choose the funded option. However, the choice had to be made in 1999 and it was irrevocable, with the exception of those eligible for early retirement.

${ }^{5}$ Detailed description of the pension reform can be found in Góra and Rutkowski (2000) and Hausner (2002) among others.

${ }^{6}$ In the case of employees born between 1949 and 1968 who did not choose the funded tier, the contribution to ZUS has been $19.52 \%$ of earnings.
} 
The original pension reform was subject to several changes introduced by the Polish government. The first public manipulation occurred in 2011 when pension fund contributions were reduced from $7.3 \%$ to $2.3 \%$. The remaining $5 \%$ was placed in a special individual sub-account created in the Social Insurance Institution (ZUS). The share of contributions allocated to the sub-accounts was initially intended to be reduced until 2017, by which time it was supposed to have dropped to $3.8 \%$ and $3.5 \%$ for ZUS and OFE accounts, respectively. However, changes were made to this scheme in 2014, via a new regulation introduced in 2013.

The new law, which went into effect on February 2014, shifted 51.5\% of the assets held by the OFEs (about 150 billion PLN ${ }^{7}$ ) to the state-run PAYG pension system, i.e. to the ZUS, including all debt securities issued and guaranteed by the State Treasury. Under the new legislation, pension funds became voluntary ${ }^{8}$. Further outflow of funds from OFEs or lack of inflow will, for example, result from the following factors:

changes in the OFEs' investment portfolio since private pension funds are no longer allowed to invest in government bonds;

gradual transfer of each person's retirement funds managed by OFE to ZUS, which will start ten years before retirement age;

automatic transfer of retirement contributions to ZUS, instead of OFE, unless an individual OFE member files a declaration requesting his/her contributions to continue to be transferred to OFE (first time-slot was between 1 April and 31 July 2014, the next will be in 2016, then every four years).

decrease in the maximum fee OFE can levy on contributions, from $3.5 \%$ to $1.75 \%$. Value of certain categories of assets in OFE portfolio (i.e. investment certificates issued by closed-end funds, units of open-ended funds or specialized open-ended funds, or units issued by foreign collective investment undertakings of the closed or open-ended type) will not be included in the overall value of total net assets managed by OFE, which means that OFEs may not charge a management fee from these assets.

The government considered the changes which took place in 2011 and 2014 necessary in order to reduce Poland's budgetary deficit. Many specialists call these changes a "significant step backward" , un-privatizing the pension system (Hagemejer et al., 2013) or even the most drastic nationalization of private assets since Soviet times (Bilefsky and Zurawik, 2013). However, Polish Prime Minister Donald Tusk claimed "it is no more than a bookkeeping change in the way to handle the public's retirement money" (Bilefsky and Zurawik, 2013).

\footnotetext{
${ }^{7}$ Approximately equal to 40-45 billion UDS or 35-38 billion EUR.

${ }^{8}$ Each employee will have four months every four years to decide whether $2.92 \%$ of their income goes to a chosen private fund or to ZUS. All employees had until the end of July 2014 to decide whether to stay in private pension funds. However, if this decision was not communicated in writing, the employee was automatically excluded from OFE.

${ }^{9}$ David McMillan, chief executive of AVIVA Europe in London, which manages a private pension fund in Poland with I 7.5 billion euros in assets (Bilefsky and Zurawik, 20I3).
} 


\section{Open pension funds operating in Poland}

Pension funds which make up the second mandatory pillar of the "new" pension system began operating in Poland in 1999. There were initially 21 OFEs but by the end of 2013 only 13 open pension funds were operating in the Polish market, with another open pension fund disappearing in 2014. In the period 1999-2013, both the number of participants and the value of assets grew steadily. By the end of December 2013, there were more than 16.3 million participants and the value of OFE assets exceeded 299 billion $\mathrm{PLN}^{10}$ (Figures 1 and 2). However, since the introduction of the new law in 2011, contributions to the pension funds have declined (Figure 3 ).

\section{Figure 1. Number of OFE members [millions] in the period 1999 - 2014}

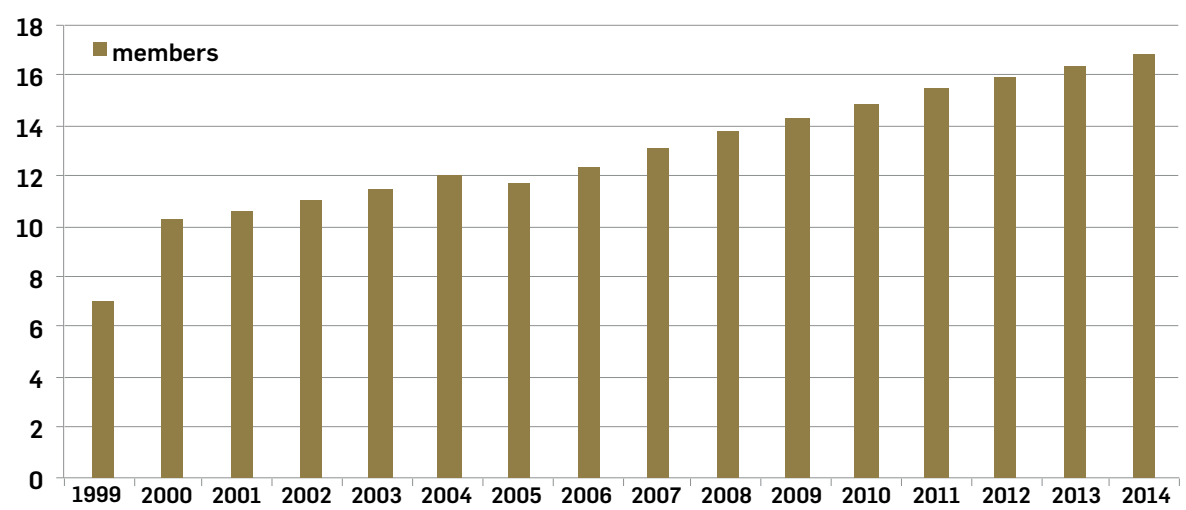

Note: all data were registered in december except 2014 data which is from september.

SOURCE: HTTP://WWW.MPIPS.GOV.PL/UBEZPIECZENIA-SPOLECZNE/UBEZPIECZENIE-EMERYTALNE/SKLADKA-NA-UBEZPIECZENIE-EMERYTALNE/; HTTP://WWW.KNF.GOV.PL/OPRACOWANIA/RYNEK_EMERYTALNY/DANE_O_RYNKU/RYNEK_OFE/DANE_MIESIECZNE/DANE_MIESIECZNE_OFE.HTML.

\section{Figure 2. OFE net assets value (billion PLN) in the period 1999 - 2014}

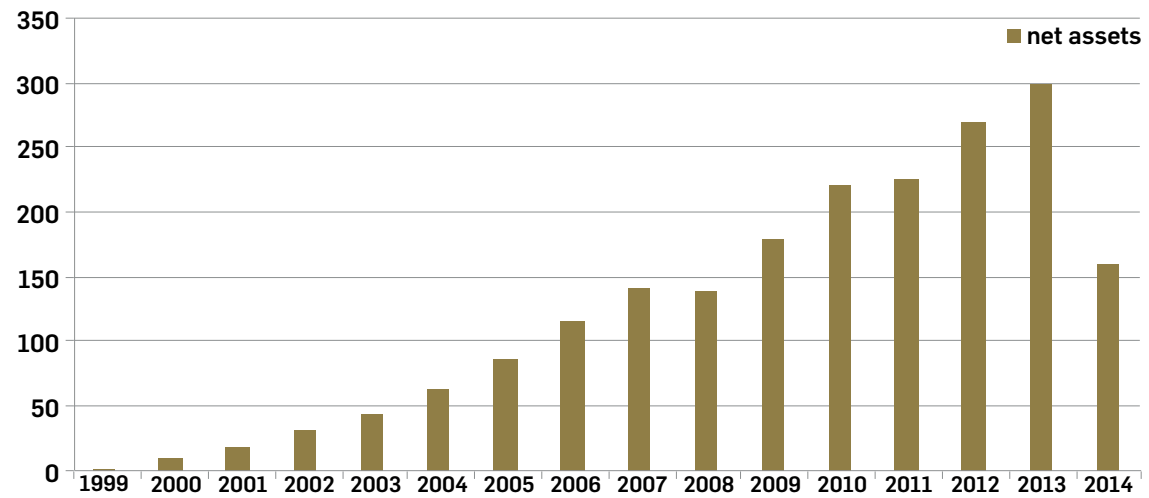

Note: all data were registered in December except 2014 data which is from September.

SOURCE: HTTP://WWW.MPIPS.GOV.PL/UBEZPIECZENIA-SPOLECZNE/UBEZPIECZENIE-EMERYTALNE/SKLADKA-NA-UBEZPIECZENIE-EMERYTALNE/; HTTP://WWW.KNF.GOV.PL/OPRACOWANIA/RYNEK_EMERYTALNY/DANE_O_RYNKU/RYNEK_OFE/DANE_MIESIECZNE/DANE_MIESIECZNE_OFE.HTML.

\footnotetext{
${ }^{10} \mathrm{http}: / /$ www.igte.com.pl/files/notowania/Dane_OFE_12_20I3.pdf.
} 
After the introduction of the changes in 2014, the value of private pension funds had fallen to 159 billion PLN ${ }^{11}$ by the end of September 2014 and it was reported that there were only 2.5 million OFE members i.e. $15.2 \%$ of employees decided to stay in the pension funds ${ }^{12}$. The value of the total contributions transferred by the Polish Financial Supervision Authority to the pension funds in September 2013 was 1050.8 million PLN while in September 2014 it was only 254.3 million PLN ${ }^{13}$.

Figure 3. Value of contributions transferred to OFE (billion PLN) in the period 1999 - 2014

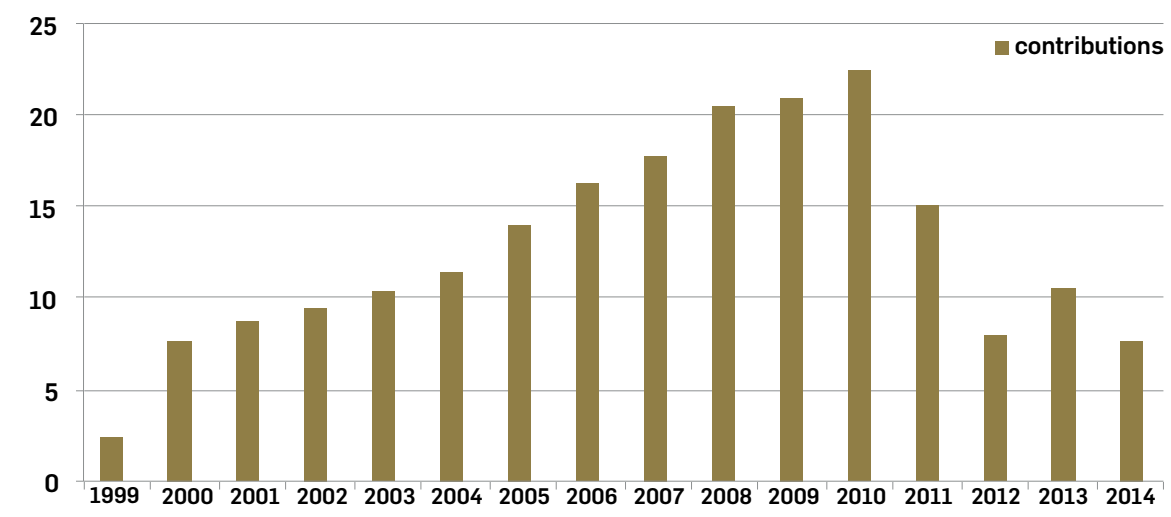

Note:All data were registered in December except for 2014 data which is from November. SOURCE: HTTP://WWW.ZUS.PL/DEFAULT.ASP?P=2\&ID= I 319 \&NAME=OF I 4 I $105 . X$ LS.

HTTP://WWW.KNF.GOV.PL/OPRACOWANIA/RYNEK_EMERYTALNY/DANE_O_RYNKU/RYNEK_OFE/DANE_MIESIECZNE/DANE_MIESIECZNE_OFE.HTML.

Open pension funds were subject to conservative investment restrictions (the original 1999 reform outlawed investment in derivatives and restricted foreign investment to $5 \%$ of the OFEs' assets, see Pelc, 2010). As a result, their losses were not as large as pension funds in other countries, which were much more severely affected by the subprime crisis and its consequences. However, Poland had some serious problems that occurred during the financial crisis. Firstly, a significant part of open pension fund profits earned for their members before the crisis were wiped out. Secondly, slower GDP growth caused an increase in the public deficit and the public debt relative to GDP. As a result, Poland was no longer meeting the Maastricht criteria.

The new regulations, introduced in 2014 , led to a change in the composition of OFEmanaged asset portfolios, not only due to the forced transfer of assets to ZUS but also due to the new rules governing OFE investment activities. According to the Polish Financial Supervision Authority ${ }^{14}$, in 2013 the OFE portfolios had greater shares of

\footnotetext{
${ }^{11}$ http://www.analizy.pl/fundusze/wiadomosci// 7222/aktywa-funduszy-emerytalnych-\%28wrzesien-20 I 4\%29.html.

${ }^{12}$ This is considered a very good result for OFE since the previous forecasts predicted that only $5 \%$ of employees would stay in OFE.

${ }^{13}$ http://www.knf.gov.pl/opracowania/rynek_emerytalny/dane_o_rynku/rynek_ofe/Dane_miesieczne/ dane_miesieczne_ofe.html.

${ }^{14}$ Source: http://www.mpips.gov.pl/ubezpieczenia-spoleczne/ubezpieczenie-emerytalne/skladka -na-bezpieczenie-emerytalnel.
} 
Treasury bonds and equity instruments than any other instruments; nearly $42 \%$ and $43 \%$, respectively. Pension funds are not currently allowed to invest in Treasury bonds and thus have to find other instruments for investments.

It is worth mentioning that it is not only the management of the fund which determines investment portfolio performance but also the condition of the market. The period 1999-2013 was characterized by different economic and financial situations in Poland. The Warsaw Stock Exchange experienced bull and bear markets that affected returns from the investments. Figure 4 compares the rates of return generated by the equity market, represented by the Warsaw Stock Exchange index WIG, and OFE in the years under study. From 2008 onwards, the OFE outperformed the Polish equity market. This does not, however, take into account the fact that OFE is prohibited from investing in debt securities issued and guaranteed by the State Treasury and that increasing the proportionate share of equity market instruments in the pension fund portfolio will improved the investment performance of pension funds in Poland.

Figure 4. Cumulative annual returns of OFE and WIG in the period $1999-2007$

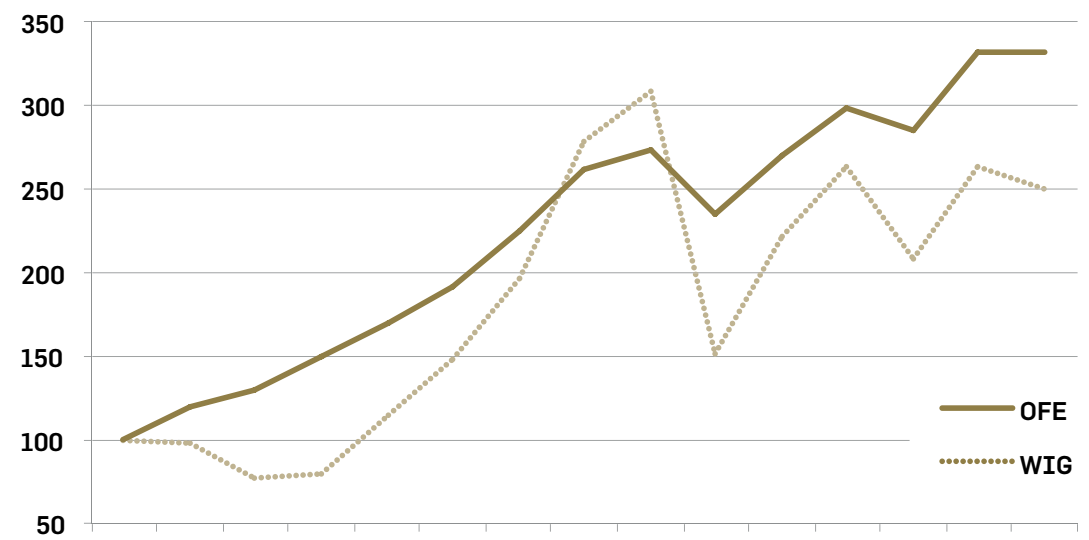

199920002001200220032004200520062007200820092010201120122013

SOURCE: HTTP://WWW.ZUS.PL/DEFAULT.ASP?P=2\&ID= | 31 9\&NAME=OF | 4 | | 05.XLS.

HTTP://WWW.KNF.GOV.PL/OPRACOWANIA/RYNEK_EMERYTALNY/DANE_O_RYNKU/RYNEK_OFE/DANE_MIESIECZNE/DANE_MIESIECZNE_OFE.HTML.

The private funds, owned by large foreign money managers such as ING, Aviva and Generali, hold assets worth about $\$ 92$ billion, which is more than one-fifth of Poland's GDP. They are among the biggest investors on the Warsaw Stock Exchange (Bilefsky and Zurawik, 2013). Also, due to high market concentration, there is a lack of price and investment competition between open pension funds; in 2011 the OFEs' commission equaled 553 million PLN while management wages equaled 981 million $\mathrm{PLN}^{15}$. This situation drew much criticism and as a result the Polish government

${ }^{15}$ See Forbes (2012). Retirement pension 201 I? 94 zł monthly, (in Polish), Forbes.pl, 28-03-20I2, [on-line:] http://www.forbes.pll artykuly/sekcje/wydarzenia/emerytura-kapitalowa-20 I I-94-zl-miesiecznie, 25588, I). 
introduced the new pension law. It is estimated that the transfer of $51.5 \%$ of OFEs' assets will lead to a decrease in Poland's public debt from around 55\% of GDP to $47 \%$ of GDP, which is the principal short-term objective of the reform rather than improved financial security for retirees (Mrowiec and Mruk-Zawirski, 2014).

\section{Methodology and data applied in research}

The aim of this research is to analyze the efficiency of private pension funds. To this end, we examine daily registered monthly logarithmic rates of return from the accounting units of 11 private pension funds operating in Poland over the entire period from 17 August 1999 to 17 October 2013 (3543 observations). The analysis is performed separately for distinct sub-periods corresponding to certain observed market trends (i.e. bull, bear and neutral markets). In looking at the monthly returns generated by the pension funds (Figure 5) we see that overall they all show a similar performance.

\section{Figure 5. Monthly rates of returns of analyzed pension funds}

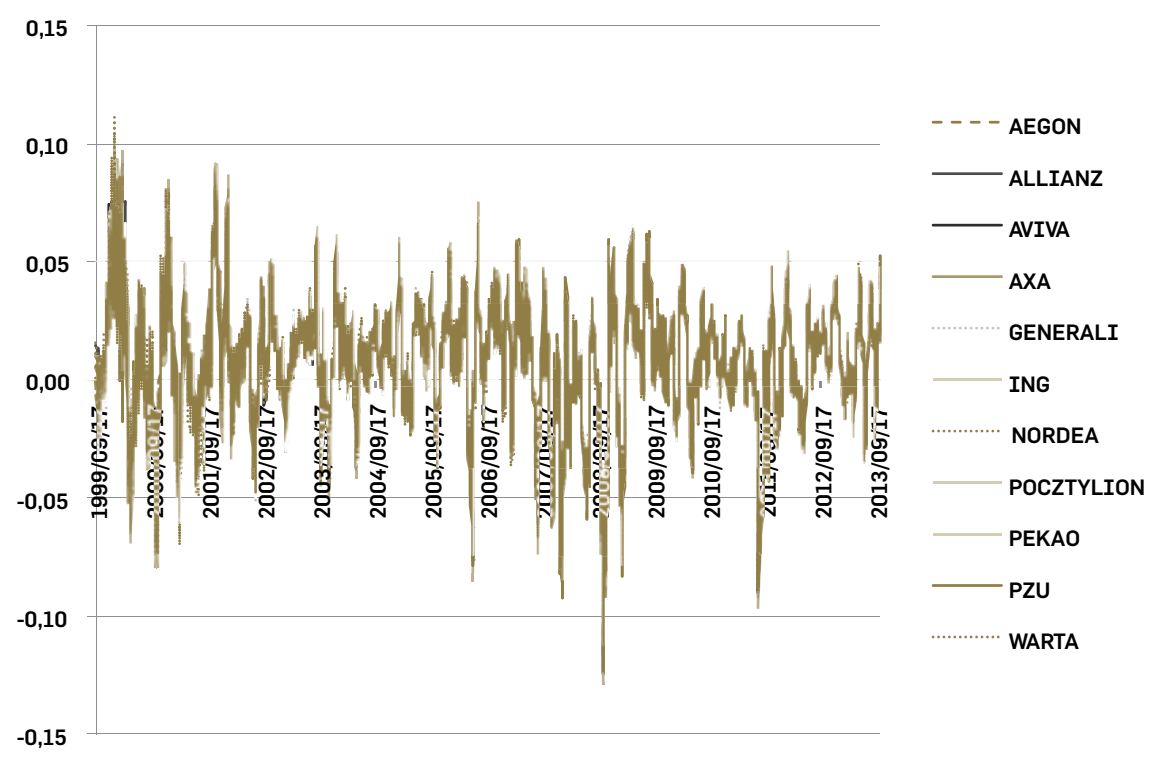

SOURCE: DOMAGAŁA (20I4).

The OFEs under study cover $85 \%$ of the market in terms of the number of pension fund members and $88 \%$ in terms of net assets (Table 1). A comparison of the analyzed funds at the end of July for the years 2013 and 2014 shows that the position of a particular pension fund in the market did not change. However, the values of the accounting units and the 3-year returns increased in 2014 in comparison to the previous year. The values of the accounting units are quite similar, ranging from 5.8 
PLN in 2013 to 6.4 PLN in 2014 (16.5\% and $17.8 \%$ of the average, respectively), and the weighted average of accounting units increased by $2.3 \%$ in 2014 in comparison to 2013 . The rates of return are more differentiated since the range is about $32 \%$ of the weighted average in both years and they increased on average by $23.8 \%$ in 2014 in comparison to returns obtained in the previous year.

Table 1. A comparison of the main characteristics of the analyzed pension funds from 31 July 2013 and 2014

\begin{tabular}{|c|c|c|c|c|c|c|c|c|c|c|}
\hline \multirow{3}{*}{$\begin{array}{l}\text { Pension } \\
\text { fund names }\end{array}$} & \multirow{3}{*}{$\begin{array}{l}\text { Fund } \\
\text { Symbol }\end{array}$} & \multicolumn{4}{|c|}{ Percentage share of the market } & \multirow{2}{*}{\multicolumn{2}{|c|}{$\begin{array}{l}\text { Accounting } \\
\text { unit }[\text { PLN] }\end{array}$}} & \multirow{2}{*}{\multicolumn{2}{|c|}{$\begin{array}{l}\text { 3-year rates } \\
\text { of return [\%] }\end{array}$}} & \multirow{3}{*}{$\begin{array}{c}\begin{array}{c}\text { Total } \\
\text { returns [\%] }\end{array} \\
2015\end{array}$} \\
\hline & & \multicolumn{2}{|c|}{ Members } & \multicolumn{2}{|c|}{ Net assets } & & & & & \\
\hline & & 2013 & 2014 & 2013 & 2014 & 2013 & 2014 & 2013 & 2014 & \\
\hline ING & ING & 18.83 & 18.45 & 23.99 & 23.98 & 37.63 & 38.31 & 17.98 & 21.79 & 295.1 \\
\hline AVIVA & AVI & 16.49 & 16.05 & 22.38 & 22.29 & 34.25 & 35.16 & 17.23 & 19.95 & 266.6 \\
\hline PZU & PZU & 13.73 & 13.40 & 13.42 & 13.40 & 34.74 & 35.68 & 15.38 & 19.61 & 265.6 \\
\hline AXA & AXA & 7.17 & 6.97 & 6.27 & 6.32 & 34.40 & 35.32 & 16.29 & 19.62 & 270.1 \\
\hline GENERALI & GEN & 6.23 & 6.05 & 5.03 & 5.02 & 35.90 & 36.39 & 14.76 & 19.45 & 279.9 \\
\hline AEGON & AEG & 5.81 & 5.62 & 4.24 & 4.26 & 33.56 & 34.56 & 15.27 & 18.68 & 260.1 \\
\hline NORDEA & NOR & 5.48 & 5.98 & 4.52 & 4.55 & 36.39 & 37.32 & 19.05 & 24.28 & 291.1 \\
\hline POCZTYLION & POC & 3.67 & 3.56 & 1.90 & 1.88 & 31.83 & 31.91 & 13.77 & 17.53 & 234.4 \\
\hline ALLIANZ & ALL & 3.43 & 4.01 & 3.04 & 3.08 & 33.18 & 33.99 & 19.13 & 21.22 & 254.9 \\
\hline PEKAO & PEK & 2.11 & 2.05 & 1.50 & 1.51 & 32.74 & 33.47 & 14.64 & 18.71 & 244.6 \\
\hline WARTA & WAR & 1.92 & 2.50 & 1.34 & 1.35 & 35.33 & 36.04 & 16.82 & 20.34 & 292.3 \\
\hline Total & & 84.87 & 84.64 & 87.63 & 87.64 & *35.15 & *35.95 & ${ }^{* *} 16.64$ & **20.60 & \\
\hline
\end{tabular}

Note:Total returns denotes the rate of return from the entire period i.e. from the first day of the pension fund's operations until 29 January 2015; * denotes weighted averages in the analyzed period, ** denotes weighted averages calculated for the period 31 March 2010 to 29 March 2013, and from 31 March 201I to 3I March 2014, respectively.

SOURCE: HTTP://WWW.IGTE.COM.PL/FLES/NOTOWANIA/DANE_OFE_07_2013.PDF, HTTP://WWW.IGTE.COM.PLFFLES/NOTOWANIA/DANE_OFE_07_2014.PDF.

Portfolio performance is usually measured by comparing their rates of return and risk measures. The former seems to be the most important factor for pension funds members when selecting a pension fund. In this study, several hypotheses are verified in order to determine whether the expected value of the analyzed rates of return and their variances differ significantly from the benchmarks. All tests are verified at the significance level of 0.05 .

The first hypothesis to be verified is whether expected returns differ from zero:

$$
H_{0}: E\left(R_{p}\right)=0
$$

using well-known test statistics:

$$
u=\frac{\bar{R}_{p}}{S_{p}} \sqrt{T}
$$


To test the significance of differences between expected rates of return generated by pension funds and the benchmarks:

$$
H_{0}: E\left(R_{p}\right)=\bar{R}_{\mathrm{B}}
$$

we employ the following test statistics:

$$
u=\frac{\bar{R}_{p}-\bar{R}_{B}}{S_{p}} \cdot \sqrt{T}
$$

where $E\left(R_{p}\right)$ is the expected rate of return of the analyzed open pension fund; $\bar{R}_{p}$ and $\bar{R}_{B}$ are the average rates of return of the analyzed portfolio and the benchmark, respectively; $S_{p}$ represents the standard deviation of rates of return generated by the pension fund; $T$ is the number of observations; and $u$ is a normally distributed statistics.

In the next step we verify the hypotheses regarding whether there is a difference between the pension fund and benchmark variances. The null hypothesis is:

$$
H_{0}: D^{2}\left(R_{p}\right)=S_{B}^{2}
$$

and the test statistics is defined as:

$$
\begin{gathered}
\chi^{2}=\frac{T S_{p}^{2}}{S_{p}^{2}} \\
u=\sqrt{2 \chi^{2}}-\sqrt{2(T-1)-1}
\end{gathered}
$$

where $D^{2}\left(R_{p}\right)$ is the variance of the portfolio, $S_{B}$ the standard deviation of rates of return generated by the benchmark, and the other symbols are as described above.

Various researchers have highlighted and documented numerous factors affecting portfolio investment efficiency performance. The two traditional measures of portfolio performance are the Treynor and the Sharpe indexes ${ }^{16}$ :

$$
\begin{gathered}
W S_{p}=\frac{\bar{R}_{p}-R_{f}}{S_{p}} \mathrm{y} \\
W T_{p}=\frac{\bar{R}_{p}-R_{f}}{\beta_{p}} \\
\beta_{p}=\frac{\sum_{t=1}^{T}\left(R_{B t}-\bar{R}_{B}\right)\left(R_{p t}-\bar{R}_{p}\right)}{\sum_{t=1}^{T}\left(R_{B t}-\bar{R}_{B}\right)^{2}}
\end{gathered}
$$

\footnotetext{
${ }^{16}$ Sharpe and Treynor ratios are composite measures of portfolio performance that also include risk (see Treynor, 1965, and Sharpe, 1966, for details). Application of Sharpe index to evaluate the private pension funds efficiency is presented in Antolin (2008).
} 
where $W S_{p}$ and $W T_{p}$ are the Sharpe and Treynor ratios, respectively; $R_{p t}$ and $R_{B t}$ are the returns of pension funds and benchmark observed in the period $t ; R_{f}$ is the average returns from the risk free instrument; $\beta_{p}$ represents the beta coefficient in the singleindex model; and the other symbols are as described above.

The ratio values (8) and (9), calculated for pension funds, are compared to the efficiency measures calculated for the constructed benchmarks, $W S_{B}$ and $W T_{B}$. The application of these traditional efficiency measures requires selection of a representative market index and risk-free instrument.

\section{Empirical analysis}

To analyze the efficiency of the pension funds we construct three hypothetical portfolios employing aggregate measures of equity, money and bond markets, represented by WIG, WIBOR ${ }^{17}$ and Treasury bonds, respectively. These portfolios (see Table 3 ) are taken as market benchmarks for evaluating the pension funds' performance. The idea behind the structure of the portfolios, which remain unchanged throughout the entire analyzed period, is to illustrate the changes concerning the structure of the pension fund portfolios resulting from the 1997 and 2013 regulations. Therefore, the first portfolio is created to reflect the 1997 change to legislation ${ }^{18}$, while the second excludes Treasury bonds in response to the new regulations of 6 December $2013^{19}$.

\section{Table 2. Simulation of the portfolios' performance in 2013}

\begin{tabular}{|c|c|c|c|c|c|}
\hline \multicolumn{2}{|c|}{$\%$ share of portfolio } & \multirow{2}{*}{$\begin{array}{c}\text { Value of Portfolio } \\
\text { [PLN] }\end{array}$} & \multicolumn{2}{|c|}{$\%$ share of portfolio } & \multirow{2}{*}{$\begin{array}{c}\text { Value of Portfolio } \\
\text { [PLN] }\end{array}$} \\
\hline Bonds & WIG & & Bonds & WIG & \\
\hline 100 & 0 & 148748 & 40 & 60 & 174559 \\
\hline 90 & 10 & 155041 & 30 & 70 & 174997 \\
\hline 80 & 20 & 160740 & 20 & 80 & 173928 \\
\hline 70 & 30 & 165696 & 10 & 90 & 171216 \\
\hline 60 & 40 & 169755 & 0 & 100 & 166734 \\
\hline 50 & 50 & 172761 & & OFE & 173088 \\
\hline
\end{tabular}

SOURCE: (KOMPA, 20I4), (KOMPA AND WIŚNIEWSKI, 20I4).

The structure of the third portfolio is defined as the optimal portfolio, simulated in line with the simplified assumption that it contains only two types of assets: shares and bonds (see Kompa, 2014; and Kompa and Wiśniewski, 2014). When modeling the dif-

\footnotetext{
${ }^{17}$ WIG is Warsaw Stock Exchange Index, and WIBOR - Warsaw Interbank Offered Rate.

${ }^{18}$ The act "Ustawa z dn. 28.08.1997 o organizacji i funkcjonowaniu funduszy emerytalnych", published in Dziennik Ustaw 1997/I39 poz. 934, came into force in 1999.

${ }^{19}$ The regulation published at http://orka.sejm.gov.pl/opinie7.nsf/nazwa/I946_u/\$file//946_u.pdf has been in effect since 20/4.
} 
ferent composition of the portfolios, the optimization criterion is the maximization of the portfolio value in 2013, assuming that superannuation in the first year equals 5000 PLN and rises by $4 \%$ annually, and with reference to real annual rates of returns generated by WIG and Treasury bonds in the period 1999-2013 (Table 2). The results from the simulations indicate that when financial market conditions change (the period under study includes different market trends), the exclusion of Treasury bonds leads to poor investment portfolio performance. The best results are produced by the portfolio composed of $30 \%$ bonds. OFE maintained its fourth-place position in the ranking.

\section{Table 3. The structure of the hypothetical portfolios}

\begin{tabular}{|c|c|c|c|}
\hline \multirow{4}{*}{ Asset representative } & \multicolumn{3}{|c|}{ Structure of the OFE portfolios due to } \\
\hline & \multicolumn{2}{|c|}{ The regulation dated to } & \multirow{2}{*}{$\begin{array}{c}\text { Kompa and } \\
\text { Wiśniewski, (2014) }\end{array}$} \\
\hline & 1997 & Dec 6, 2013 & \\
\hline & Portfolio 1 & Portfolio 2 & Portfolio 3 \\
\hline Bond market: Treasury Bonds & $42 \%$ & - & $30 \%$ \\
\hline Equity market: WIG & $46 \%$ & $79 \%$ & $70 \%$ \\
\hline Monetary market: WIBOR & $12 \%$ & $21 \%$ & - \\
\hline
\end{tabular}

SOURCE: OWN ELABORATION.

The next step of our analysis is to verify the hypotheses that expected returns and risk generated by the pension funds equal the rates of return and variance of the benchmark in the entire analyzed period (Table 4). It is clear that returns from the pension portfolios are greater than those from all benchmarks, and the variances of all the portfolios are smaller than those of the benchmarks. Therefore it can be said that the open pension funds investment policy was quite effective.

\section{Table 4. Values of the test-statistics}

\begin{tabular}{|c|c|c|c|c|c|c|}
\hline \multirow{4}{*}{ OFEs } & \multicolumn{6}{|c|}{ Hypotheses } \\
\hline & \multicolumn{3}{|c|}{$H_{0}: E\left(R_{p}\right)=E\left(R_{B}\right)$} & \multicolumn{3}{|c|}{$H_{0}: D^{2}\left(R_{p}\right)=\sigma_{0}^{2}$} \\
\hline & \multicolumn{3}{|c|}{ Portfolio no. } & \multicolumn{3}{|c|}{ Portfolio no. } \\
\hline & 1 & 2 & 3 & 1 & 2 & 3 \\
\hline AEGON & 13.582 & 10.063 & 5.866 & -29.856 & -51.174 & -46.857 \\
\hline ALLIANZ & 14.962 & 11.434 & 7.224 & -30.013 & -51.269 & -46.965 \\
\hline AVIVA & 13.731 & 10.503 & 6.651 & -24.98 & -48.212 & -43.507 \\
\hline AXA & 14.595 & 11.07 & 6.865 & -29.956 & -51.235 & -46.926 \\
\hline GENERALI & 14.654 & 11.295 & 7.289 & -27.268 & -49.602 & -45.079 \\
\hline ING & 13.822 & 10.811 & 7.22 & -20.696 & -45.61 & -40.565 \\
\hline NORDEA & 15.118 & 11.624 & 7.457 & -29.473 & -50.941 & -46.593 \\
\hline POCZTYLION & 12.784 & 9.516 & 5.618 & -25.692 & -48.645 & -43.997 \\
\hline PEKAO & 13.284 & 9.97 & 6.016 & -26.514 & -49.144 & -44.561 \\
\hline PZU & 14.072 & 10.762 & 6.813 & -26.443 & -49.101 & -44.512 \\
\hline WARTA & 13.572 & 10.38 & 6.573 & -24.292 & -47.794 & -43.035 \\
\hline
\end{tabular}

SOURCE: OWN ELABORATION. 
Due to the changing situation of the Warsaw Stock Exchange (as shown in WIG daily quotations), the analysis is further expanded to five distinct sub-periods:

17.09.1999 - 20.11.2003 stagnation 1,

21.11.2003 - 06.07.2007 bull market 1,

07.07.2007 - 17.02.2009 bear market,

18.02.2009 - 18.07.2011 bull market 2,

19.07.2011 - 17.10.2013 stagnation 2.

For these periods, the Sharpe and Treynor ratios are calculated for all the pension funds and their performance is compared to the efficiency of the constructed benchmarks. The risk-free instrument is represented by Treasury bonds.

Table 5. Sharpe and Treynor ratios calculated for hypothetical portfolios

\begin{tabular}{|c|c|c|c|c|c|c|}
\hline \multirow{3}{*}{ Period } & \multicolumn{6}{|c|}{ Type of ratio: } \\
\hline & Sharpe & Treynor & Sharpe & Treynor & Sharpe & Treynor \\
\hline & \multicolumn{2}{|c|}{ Portfolio 1} & \multicolumn{2}{|c|}{ Portfolio 2} & \multicolumn{2}{|c|}{ Portfolio 3} \\
\hline Stagnation 1 & 0.027 & 0.001 & 0.026 & 0.002 & 0.085 & 0.005 \\
\hline Bull market 1 & 0.400 & 0.011 & 0.456 & 0.020 & 0.472 & 0.019 \\
\hline Bear market & -0.565 & -0.026 & -0.607 & -0.045 & -0.614 & -0.040 \\
\hline Bull market 2 & 0.390 & 0.012 & 0.419 & 0.020 & 0.413 & 0.018 \\
\hline Stagnation 2 & -0.067 & -0.002 & -0.069 & -0.003 & 0.034 & 0.001 \\
\hline
\end{tabular}

SOURCE: OWN ELABORATION.

Analysis of the data presented in Tables 5 and 6 reveals that all pension funds are more efficient than constructed benchmarks. To calculate the Treynor ratios, three versions of the single-index models are estimated for each pension fund. The construction of these model differs with respect to the market index, which is represented by the constructed portfolios. In comparing the performance of all 11 pension funds to the benchmarks it is clear that all Treynor measures (Table 7) calculated for the pension funds exceed those calculated for the market benchmarks in all the analyzed subperiods, except the bear market for pension fund PEKAO and for portfolios 1 and 2.

\section{Table 6. Sharpe ratios calculated for pension funds}

\begin{tabular}{|c|c|c|c|c|c|c|c|c|c|c|c|}
\hline$\frac{\text { D }}{\frac{0}{0}}$ & $\begin{array}{l}\mathbf{Z} \\
\text { 总 } \\
\text { }\end{array}$ & 突 & 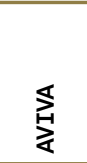 & $\underset{<}{\overleftarrow{x}}$ & 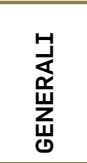 & $\sum_{Z}^{0}$ & 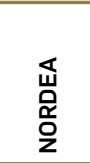 & 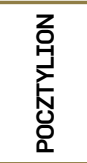 & $\frac{\text { 옴 }}{\text { 㟧 }}$ & $\underset{\mathbf{\alpha}}{\stackrel{2}{N}}$ & $\frac{\mathbb{k}}{\frac{\alpha}{\alpha}}$ \\
\hline Stagnation 1 & 0.522 & 0.531 & 0.494 & 0.487 & 0.476 & 0.463 & 0.587 & 0.413 & 0.394 & 0.551 & 0.434 \\
\hline Bull market 1 & 0.548 & 0.562 & 0.569 & 0.607 & 0.607 & 0.529 & 0.527 & 0.579 & 0.676 & 0.561 & 0.608 \\
\hline Bear market & -0.454 & -0.460 & -0.468 & -0.445 & -0.457 & -0.434 & -0.463 & -0.461 & -0.538 & -0.435 & -0.497 \\
\hline Bull market 2 & 0.577 & 0.599 & 0.565 & 0.580 & 0.559 & 0.561 & 0.596 & 0.571 & 0.579 & 0.521 & 0.571 \\
\hline Stagnation 2 & 0.230 & 0.259 & 0.249 & 0.282 & 0.253 & 0.260 & 0.298 & 0.221 & 0.236 & 0.236 & 0.266 \\
\hline
\end{tabular}

SOURCE: OWN ELABORATION. 
Table 7. Treynor ratios for pension funds for different portfolios representing market benchmarks in the Sharpe models

\begin{tabular}{|c|c|c|c|c|c|c|c|c|c|c|c|}
\hline$\frac{\overline{0}}{\frac{0}{0}}$ & $\begin{array}{l}\mathbf{z} \\
\text { 岁 } \\
\text { « }\end{array}$ & 胥 & 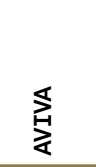 & $\underset{x}{\mathbb{x}}$ & 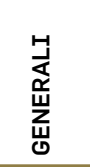 & $\sum_{i=1}^{0}$ & 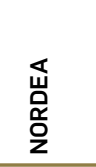 & 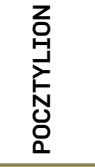 & $\begin{array}{l}\frac{0}{\alpha} \\
\frac{\mathbf{z}}{\mathrm{a}}\end{array}$ & $\underset{\mathbf{N}}{\vec{N}}$ & $\frac{\mathbb{k}}{\frac{\alpha}{k}}$ \\
\hline & \multicolumn{11}{|c|}{ Portfolio 1} \\
\hline Stagnation 1 & 0.025 & 0.027 & 0.023 & 0.024 & 0.022 & 0.023 & 0.029 & 0.020 & 0.021 & 0.028 & 0.021 \\
\hline Bull market 1 & 0.016 & 0.017 & 0.017 & 0.018 & 0.018 & 0.016 & 0.016 & 0.017 & 0.020 & 0.017 & 0.018 \\
\hline Bear market & -0.022 & -0.023 & -0.023 & -0.022 & -0.022 & -0.021 & -0.023 & -0.023 & -0.027 & -0.022 & -0.025 \\
\hline Bull market 2 & 0.018 & 0.019 & 0.018 & 0.018 & 0.018 & 0.018 & 0.019 & 0.018 & 0.018 & 0.016 & 0.018 \\
\hline \multirow[t]{2}{*}{ Stagnation 2} & 0.007 & 0.008 & 0.007 & 0.008 & 0.007 & 0.008 & 0.009 & 0.006 & 0.007 & 0.007 & 0.008 \\
\hline & \multicolumn{11}{|c|}{ Portfolio 2} \\
\hline Stagnation 1 & 0.038 & 0.042 & 0.035 & 0.037 & 0.034 & 0.035 & 0.045 & 0.030 & 0.033 & 0.043 & 0.032 \\
\hline Bull market 1 & 0.026 & 0.026 & 0.027 & 0.028 & 0.028 & 0.025 & 0.024 & 0.027 & 0.031 & 0.026 & 0.029 \\
\hline Bear market & -0.037 & -0.038 & -0.038 & -0.037 & -0.037 & -0.036 & -0.038 & -0.038 & -0.045 & -0.036 & -0.041 \\
\hline Bull market 2 & 0.030 & 0.031 & 0.029 & 0.030 & 0.028 & 0.029 & 0.031 & 0.029 & 0.029 & 0.027 & 0.029 \\
\hline \multirow[t]{2}{*}{ Stagnation 2} & 0.012 & 0.013 & 0.012 & 0.014 & 0.013 & 0.013 & 0.015 & 0.011 & 0.012 & 0.012 & 0.013 \\
\hline & \multicolumn{11}{|c|}{ Portfolio 3} \\
\hline Stagnation 1 & 0.032 & 0.036 & 0.030 & 0.031 & 0.029 & 0.030 & 0.039 & 0.026 & 0.028 & 0.036 & 0.028 \\
\hline Bull market 1 & 0.022 & 0.023 & 0.023 & 0.025 & 0.025 & 0.022 & 0.021 & 0.024 & 0.028 & 0.023 & 0.025 \\
\hline Bear market & -0.031 & -0.032 & -0.032 & -0.030 & -0.031 & -0.030 & -0.032 & -0.031 & -0.037 & -0.030 & -0.034 \\
\hline Bull market 2 & 0.026 & 0.028 & 0.026 & 0.027 & 0.025 & 0.026 & 0.028 & 0.026 & 0.026 & 0.024 & 0.026 \\
\hline Stagnation 2 & 0.010 & 0.011 & 0.011 & 0.012 & 0.011 & 0.011 & 0.013 & 0.010 & 0.010 & 0.010 & 0.012 \\
\hline
\end{tabular}

SOURCE: OWN ELABORATION.

The analyses of efficiency measures calculated for the hypothetical portfolios show that portfolio 3 seems to be the most efficient, especially in terms of the Sharpe ratio.

\section{Conclusions}

The changing demographics of the Polish population is reflected in the increase in the old-age dependency ratio from 15.26 in 1989 to 17.75 in 1999, and 19.32 in 2011, thus necessitating a general reform of the pension system. Such a reform was carried out in 1999, whereby the pay-as-you-go system was replaced by the threepillar, partly funded system. However, more recent legislation, introduced in 2011 and 2013, significantly limited the effectiveness of the mandatory funded pillar and created a situation whereby pension funds hold most of their assets in shares of companies listed on the Warsaw Stock Exchange and are relegated to an increasingly peripheral role in managing Poles' future retirement benefits. 
This study shows that regardless of the general conditions of the capital market, the pension funds outperform the constructed benchmarks. It shows that the ability to diversify a portfolio (as established in the 1999 reform) protects pensioners' interests better than hypothetical portfolios, as can be observed by analyzing the cumulative returns from OFE (Figure 4). Our research shows that the new regulations, especially those that resulted in restructured pension fund portfolios, did not improve pension fund performance.

\section{Acknowledgement}

This research is made possible by a grant for the "Analysis of Open Pension Funds Market as Compared to the Open Investment Funds Market Functioning in Poland" 2013/09/B/HS4/ 00493 financed by National Science Center.

\section{References}

Antolin, P. (2008). Pension Fund Performance, OECD Working Papers on Insurance and Private Pensions, No. 20, OECD publishing, (C) OECD. doi:10.1787/240401404057

Bilefsky, D. and Zurawik, M. (2013). Polish Plan on Pensions Arouses Sharp Criticism. In The New York Times, October, 9, 2013. Available at: http://www.nytimes.com/2013/10/10/business/international/polish-plan-onpensions-arouses-sharp-criticism.html?_r=0 (last access: Feb. 2015).

Domagata, M. (2014). Benchmark construction for OFE, Master Thesis, SGGW, Warsaw.

Feldstein, M. (1997). Transition to a Fully Funded Pension System: Five Economic Issues. NBER Working Paper No. 6149. Available at: http://www.nber.org/papers/w6149.pdf [last access: Feb. 2015].

FORBES (2012). Retirement pension 2011? 94 zt monthly (in Polish) in Forbes.pl, 28-03-2012. Available at: http://www.forbes.pl/artykuly/sekcje/wydarzenia/emerytura-kapitalowa-2011-94-zl-miesiecznie, 25588,1) [last access: February 2015].■

Góra, M. and Rutkowski, M. (2000). The quest for pension reform: Poland's security through diversity. William Davidson Institute Working Papers Series 286, William Davidson Institute at the University of Michigan. Available at: http://deepblue.lib.umich.edu/bitstream/handle/2027.42/396 70/wp286.pdf?sequence=3 (last access: February 2015).

Góra, M. (2001). Cost, savings and externalities associated with the introduction of the new pension system, Zeszyty BRE Bank - CASE, 57, pp. 7-36 (in Polish).

Hagemejer, J., Makarski, K. and Tyrowicz, J. (2013). Unprivatizing the Pension System: The Case of Poland. University of Warsaw, Faculty of Economic Sciences, Working Paper No. 26/2013(111), Warsaw. 
Hausner, J. (2002). Poland Security through Diversity. In Feldstein M. and Siebert H. (Eds.), Social Security Pension Reform in Europe, University of Chicago Press, pp. 349-364. Available at: http://www.nber.org/chapters/ c10678.pdf (last access: February 2015).

Kompa, K. (2014). Polish Pension System in Transition: Impact on the Investment Portfolio Construction, Indian Journal of Fundamental and Applied Life Sciences, 4 (S1) April-June, pp. 2102-2110. Available at: http://www.cib tech.org/sp.ed/jls/2014/01/jls.htm (chapter 236). $\square$

Kompa, K. and Wiśniewski, T. (2014). Security Through Diversity: Portfolio Diversification of Private Pension Funds, Quantitative Methods in Economics, Vol. XV, 1, pp. 58-65.

Marcinkiewicz, E. (2011). Changing the rules for distribution of pension contributions and the importance of pension funds in the financial market, Polityka Spoteczna. Numer Specjalny, Warszawa, pp. 16-19, (in Polish).

Mrowiec Z. and Mruk-Zawirski P. (2014). How the Polish pension fund reform will affect the fund's investments, Allen and Overy, Warsaw, Poland.

Pelc, P. (2010). Polish Pension Reform - Lost Decade? Available at: http://www.pawelpelc.pl/index.php?display= 5\&artykul=167 (last access: February 2015).

Pensions at a Glance (2013): OECD and G20 Indicators (C) OECD 2013.

Roztucki, W. (2001). The importance of pension funds for the development of the Warsaw Stock Exchange, BRE Bank-CASE, 57, pp. 37-41, Warsaw, (in Polish).

Rynkiewicz, M. (2014). OFE flee abroad. How many billions will evaporate from the stock market? (in Polish). Available at: http://www.money.pl/gospodarka/wiadomosci/artykul/ofe-uciekna-za-granice-ile-miliardow, 245,0,1651189.html (last accessed: February 2015).

Security (1997). Security through diversity: Reform of the pension system in Poland, Office of the Government Plenipotentiary for Social Insurance Reform, Warsaw, Poland.

Sharpe, W. F. (1966). Mutual Fund Performance, Journal of Business, 39(1), pp. 119-138.

Sinn, H.W. (2000). Why a Funded Pension System Is Useful and Why It Is Not Useful. National Bureau of Economic Research Working Paper 7592, Available at: http://www.nber.org/papers/w7592 (last access: February 2015).

Treynor, J.L. (1965). How to Rate Management of Investment Funds, Harvard Business Review, 43(1), pp. 63-75. 
